\title{
A Feminist Study of Manju Kapur's A Married Woman
}

\section{OPEN ACCESS}

Volume: 8

Issue: 1

Month: December

Year: 2019

P-ISSN: 2320-2645

E-ISSN: 2582-3531

Received: 08.10.2019

Accepted: 12.11.2019

Published: 01.12.2019

Citation:

Prasad, Krishna S., and AJ Manju. "A Feminist Study of Manju Kapur's A Married Woman.” Shanlax International Journal of English, vol. 8, no. 1, 2019, pp. 61-62.

DOI:

https://doi.org/10.34293/ english.v8i1.1267

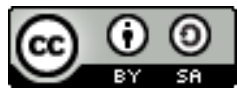

This work is licensed under a Creative Commons AttributionShareAlike 4.0 International License

\section{Krishna S Prasad}

Assistant Professor, Department of English,

Sree Narayana Guru College, Coimbatore, Tamilnadu, India

\author{
AJ.Manju \\ Associate Professor \& Head, Department of English \\ Sree Narayana Guru College, Coimbatore, Tamilnadu, India
}

\begin{abstract}
Postmodern tendencies have been reflected in Indian writing in English over the past few years. This paves the way for the creation of new socio-cultural and political situation and circumstances that pushes the marginal or the extreme marginal to the center stage. Feminism as it is an accompanying issue of postmodernism is the product of such a sensibility. The novel $A$ Married Women is heavily plotted. It traces the life of Astha from her young adulthood through her early middle years. In the process, she dates with a couple of young men of her own choice like her western counter parts, marries a man of her parents "choice and discovers the joys of intimacy with her husband, begets children, yet grows distant from him, and struggles to become a painter. She reflects the middle-class values and seems to enjoy her mental bliss for a long time but gradually experiences that there is something certainly lacking in her life.

Keywords: ManjuKapur, Married Woman, Postmodern literature, Difficult Daughters,
\end{abstract} Ashta, Literary Polyrhythms.

\section{Full Paper}

A famous writer Manju Kapur is from Amritsar in India. Her First Book Difficult Daughters won the best booker prize in Europe and South Asia. She studied M.A in 1972 at Dalhousie University, Canada, and she got an M. Phil., from Delhi University. Manju Kapur is the most renowned woman Writer of India. Kapur has successfully portrayed the conflict of tradition and modernity in her characters. Her writings are merely an analysis of female characters and cultural identity. She narrated her characters in a real way, who tries to break the tradition of silence.

A Married Woman, a well-known novel of her published in 2003. It is the story of Astha, a young lady from Delhi, in a typical middle-class family. She is the protagonist, who is the only daughter of her parents. The father wants her to be successful and independent in her professional career, and her mother dreams of her daughter to be a traditional housewife in a happy family. The problem arises when she looks for a boyfriend and to be engaged in marriage to him. Two boys come in her contact, but the relationship ends up with her sorrow only. Finally, she makes an arranged marriage which her parents want. Her mother's commitment to her husband ultimately leads her to think that the happy relationship between her mother and father should be her aim in life. Astha finds a teaching job in a school, but her husband does not attach any importance to it. Her husband received a degree in MBA, and at a certain point in their conjugal life, a problem crops up as to whether the birth of a male offspring depends on the female or male sex. This difference of opinion makes her husband be indifferent and unconcerned to Ashta. 
Ashta meets Aijaz, a Muslim social activist. He is a good supporter of her literary career. Aijaz's premature death during the traumatic Hindu-Muslim riot converted her into a secular person. She met a lady named Pippelika Khan, a widow and lesbian with whom she found sexual pleasure. She wants her husband and her lesbian friend under the same roof. Her husband found some difficulties in this matter.

In this novel, Kapur describes the self-identity of female characters. Kapur shows that women are not rubber balls or decorative ornaments. The novel shows the cleavage between the characters of two generations. She narrates the middle-class family values and customs and gives importance to femaleIdentity in her novel. She highlights the factor which curbs the freedom of the female to live, grow, and actualize herself the way men do. How religion, tradition, and myth are misused to condition women into an acceptance of their secondary status, causing them to lead circumscribed lives. She has tried to evolve her stream of the emergence of new women grounded in reality.

Manju Kapur closely observes the craving of a woman for her identity. Her work narrated the plight of Indian ladies in the present scenario. This novel reflects the struggle of women for their self-identity. She continues with the theme of female struggle and her strive for breaking up of the shackles of cruel tradition. The protagonist Astha is the symbol of the woman striving to gain their space in life and sociocultural domains.

The novelist focuses on the condition of a married woman in Indian society. She also describes the plight of a woman through the protagonist of the novel. Manju Kapur always observed the life of young women and their sufferings in Indian society. She narrated different women from different social classes in her novels. She is a new writer who struggles against social customs, and she wants to break the tradition of silence.

This novel is showing that women are helpless in the family. They have no right to voice their opinions and do not have their own identity. They should work like a machine without hope and emotions. Their lives are revolving around with their husbands. Asthma is the representative of a modern woman who was still confined in tradition and male domination. Astha and Pipeelika are new women of the postmodern era who adopt the means of empowerment for selfsatisfaction. They deconstruct every possibility of self-reliance and struggle towards absolute freedom from social and economic constraints.

Astha and Pipeelika are always in search of their individuality. Postmodern women cannot bear sex suppression and subjugation. In socio-political aspects of life, they want co-existence and equal handling. They would not bear social aggression.

\section{References}

Kapur, Manju. A Married Woman, Roli Books Ltd. New Delhi, 2006.

Robert Gnanamony, S. The Rationale of Sexual Diversity in Manju Kapur's A Married Woman, Sarup and Sons, New Delhi, 2005.

\section{Author Details}

Krishna S Prasad, Assistant Professor, Department of English, Sree Narayana Guru College, Coimbatore, Tamil Nadu, India, Email ID: rkr34484@gmail.com

Dr.AJ.Manju, Associate Professor \& Head, Department of English, Sree Narayana Guru College, Coimbatore, Tamil Nadu, India 